\title{
Understanding the Links between Project Success and Technology Usage via Work Function Characteristics
}

\author{
James T. O'Connor ${ }^{1}$ and Li-Ren Yang ${ }^{2}$ \\ ${ }^{1}$ Professor, Department of Civil Engineering, ECJ 5.2, The University of Texas, Austin, TX 78712, \\ jtoconnor@mail.utexas.edu \\ ${ }^{2}$ Graduate Research Assistant, Department of Civil Engineering, ECJ 5.2, The University of Texas, \\ Austin,TX78712,lry@mail.utexas.edu
}

\begin{abstract}
More than 200 capital facility projects from across the U.S. have been assessed on the issue of technology usage at the work function level and overall project cost and schedule success. Work functions (WFs) that may leverage project cost and schedule performance were identified. The analyses suggested that degrees of technology used in executing these project performance-leveraging work functions may have a significant impact on project cost or schedule performance.

This paper explores the links between technology utilization and project success in further detail. The techniques used for analyzing the associations include cost performance sensitivity, schedule performance sensitivity, and analysis of Work Function Characteristics (WFCs). Cost and schedule performance sensitivity analyses of project performance-leveraging work functions are employed as a way to gain greater understanding of the connection between technology usage and project performance. In addition, WFCs were investigated as an additional basis for gaining deeper insights into how technology usage may impact project success. The analysis results indicate that information \& data intensive, human resource involved, and management-related WFCs can positively influence project cost and schedule success.
\end{abstract}

KEYWORDS: Project Success; Technology Utilization; Work Function; Work Function Characteristics.

\section{INTRODUCTION}

An industry-wide survey was used to collect project data from more than 200 capital facility projects on the issue of technology usage at the work function (WF) level and overall project success. Work functions that may leverage project cost and schedule performance were identified [O'Connor and Yang 2002]. The analyses suggested that degrees of technology used in executing these work functions may have a significant impact on project cost or schedule performance. These cost and schedule performance-leveraging work functions were further analyzed using cost performance sensitivity, schedule performance sensitivity, and Work Function Characteristics (WFCs) analysis to explain the links between technology utilization and project success.

Work Function Characteristics are differentiae that characterize the work functions. Six categories of Work Function Characteristics were developed to classify work functions by their attributes and as a way to study differences between work functions relative to technology usage: 1) nature of work function procedures, 2) time/space/cost factors, 3) information and data aspects, 4) WF management, 5) nature of WF product, and 6) nature of human resource [O'Connor and Won 2002]. Table 1 presents a list of the 31 Work Function Characteristics by category (not all WFCs can be applied to each work function).

Work Function Characteristics were used to better understand project performance-leveraging work functions through analysis of their attributes. WFC analysis reveals characteristics common to the cost and schedule performance-leveraging work functions. To gain more insight into how the use of technology affects project success, the following research hypothesis was developed:

Hypothesis: Work Function Characteristics can, in part, explain the links between project success and technology utilization. 
Table 1. List of WFCs by Category

\begin{tabular}{l}
\hline H) Human Resource \\
H2: Many individuals are involved to perform WF \\
skills and specialties \\
H3: User's, worker's or operator's experience is \\
critical to performance \\
\hline (P) Work Function Product \\
\hline P1: Performance of many subsequent WFs relies \\
heavily on this WF \\
P2: WF product is physically large and bulky \\
P3: Errors are difficult to fix or require a large amount \\
of resources to fix \\
\hline T) Time/Space/Cost \\
\hline T1: WF is a critical path activity in most cases \\
T2: WF activity requires spatial coordination \\
T3: WF involves relatively high uncertainty in the \\
following item (cost, schedule, quality, and safety) \\
T4: WF management operates in close proximity to \\
workers \\
T5: WF involves environmental hazard \\
T6: WF is costly to execute \\
\hline
\end{tabular}

\section{(I) Information \& Data}

I1: WF involves uncertainty information

I2: Historical data from previous projects are required for execution

I3: WF relies on industry technical standards

I4: WF data are in many different formats

I5: Data accuracy is crucial to successful WF performance

I6: Security of related data is very important I7: WF involves significant amount of data updating

\section{(M) Management}

M1: A specialty organization is involved in most cases

M2: Many different types of organizations are involved

M3: Primary performance driver of the WF is one of the followings (quality, safety, cost, and schedule)

M4: Responsible individual must communicate

frequently with others

M5: WF involves high probability of change

\section{(D) Work Procedure}

D1: WF involves iterations and revisions

$\mathrm{D} 2$ : WF is error prone

D3: WF procedures are driven by regulations

D4: WF involves repetitive activity

D5: Some WF resources are often idle

D6: WF procedures are very complex

D7: WF relies on or requires physical output products of many previous WF.
This paper explores the links between technology utilization and project success in further detail. Cost and schedule performance sensitivity analyses of project performance-leveraging work functions are employed as a way to gain greater understanding of the connection between technology usage and project performance. In addition, WFCs were investigated as an additional basis for gaining deeper insights into how technology usage may impact project success.

\section{COST PERFORMANCE SENSITIVITY}

According to the analysis of technology usage at the work function level, a total of 19 work functions that may leverage project cost performance were identified [O'Connor and Yang 2002]. Table 2 presents these cost performance-leveraging WFs. It is reasonable to think that these work functions involve factors or characteristics that may affect the cost performance of a project. Cost performance sensitivity analysis of these work functions may provide some explanation of the connection between technology utilization and project cost success. Seven of the 19 cost performanceleveraging work functions are thought to be costsensitive. These cost-sensitive work functions involve significant financial expenditure or are closely associated with cost control.

\section{SCHEDULE PERFORMANCE SENSITIVITY}

Table 3 lists the 18 work functions that may leverage project schedule performance [O'Connor and Yang 2002]. These schedule performanceleveraging work functions as a matter of logic involve factors or characteristics that likely affect the schedule performance of a project. Schedule performance sensitivity analysis of these work functions may be helpful in explaining the connection between technology utilization and project schedule success. Nine of the 18 schedule performance-leveraging work functions are thought to be schedule-sensitive. These schedule-sensitive work functions involve significant time duration or are closely associated with schedule control. 
Table 2. List of Cost Performance-Leveraging WFs

\begin{tabular}{|c|c|c|}
\hline ID & Work Function & $\begin{array}{l}\text { Thought to } \\
\text { Be Cost- } \\
\text { Sensitive }\end{array}$ \\
\hline 1.01 & $\begin{array}{l}\text { Conduct market analysis or need } \\
\text { analysis for a new facility }\end{array}$ & $\mathrm{X}$ \\
\hline 1.03 & Model user's process & $\mathrm{X}$ \\
\hline 2.05 & Prepare floor plans & \\
\hline 2.08 & Design electrical systems & \\
\hline 2.09 & Design HVAC systems & \\
\hline 2.10 & $\begin{array}{l}\text { Document the assumptions used in } \\
\text { developing the budget, and pass to } \\
\text { next phase }\end{array}$ & $\mathrm{X}$ \\
\hline 2.14 & Track design progress & \\
\hline 3.03 & $\begin{array}{l}\text { Link quantity survey data to the cost } \\
\text { estimating process }\end{array}$ & $\mathrm{X}$ \\
\hline 4.06 & $\begin{array}{l}\text { Track the inventory of materials on } \\
\text { site }\end{array}$ & $\mathrm{X}$ \\
\hline 4.10 & $\begin{array}{l}\text { Constructors provide feedback about } \\
\text { the effects of design changes on cost } \\
\text { and schedule }\end{array}$ & $X$ \\
\hline 4.13 & Update as-built drawings & \\
\hline 4.15 & Owner payment to contractor & \\
\hline 5.07 & Fabricate roof trusses & \\
\hline 6.02 & Train facility operators & \\
\hline 6.03 & $\begin{array}{l}\text { Use as-built information in operator } \\
\text { training }\end{array}$ & \\
\hline 6.06 & Monitor equipment operations & \\
\hline 6.08 & $\begin{array}{l}\text { Update as-built drawings in response } \\
\text { to facility modifications }\end{array}$ & \\
\hline 6.09 & $\begin{array}{l}\text { Monitor/track/control facility energy } \\
\text { usage }\end{array}$ & $X$ \\
\hline 6.10 & $\begin{array}{l}\text { Monitor environment impact from } \\
\text { operations }\end{array}$ & \\
\hline
\end{tabular}

\section{WFC ANALYSIS AND DATA COLLECTION}

In order to identify characteristics associated with the cost/schedule performance-leveraging work functions, a total of 10 project performanceleveraging work functions were selected for analysis. The selected work functions for Work Function Characteristic analysis are listed in Table 4. The data collection effort involved characterization of these selected work functions. For the selected work functions, data were collected from 11 industry professionals from the Owner, $\mathrm{A} / \mathrm{E}$, or GC groups. Respondents to the survey included presidents, vice presidents, project managers, project engineers, and project planners. These professionals averaged 22 years of experience, with a minimum of 12 years and a maximum of 30 years.

Table 3. List of Schedule Performance-Leveraging WFS

\begin{tabular}{|c|c|c|}
\hline ID & Work Function & \begin{tabular}{|c|} 
Thought to Be \\
Schedule- \\
Sensitive
\end{tabular} \\
\hline 1.01 & $\begin{array}{l}\text { Conduct market analysis or need } \\
\text { analysis for a new facility }\end{array}$ & $\mathrm{X}$ \\
\hline 1.02 & $\begin{array}{l}\text { Develop, evaluate, and refine the } \\
\text { project's scope of work }\end{array}$ & $\mathrm{X}$ \\
\hline 1.03 & Model user's process & \\
\hline 1.05 & $\begin{array}{l}\text { Develop a milestone schedule from } \\
\text { the scope of work }\end{array}$ & $\mathrm{X}$ \\
\hline 2.11 & Detect physical interferences & $\mathrm{X}$ \\
\hline 3.04 & $\begin{array}{l}\text { Link between supplier cost quotes } \\
\text { and cost estimate }\end{array}$ & \\
\hline 3.09 & $\begin{array}{l}\text { Acquire \& review shop drawings; } \\
\text { send response }\end{array}$ & $\mathrm{X}$ \\
\hline 4.01 & $\begin{array}{l}\text { Develop detailed construction } \\
\text { schedule }\end{array}$ & $\mathrm{X}$ \\
\hline 4.09 & $\begin{array}{l}\text { Communicate Requests for } \\
\text { Information \& response }\end{array}$ & $\mathrm{X}$ \\
\hline 4.10 & $\begin{array}{l}\text { Constructors provide feedback about } \\
\text { the effects of design changes on cost } \\
\text { and schedule }\end{array}$ & $\mathrm{X}$ \\
\hline 4.14 & $\begin{array}{l}\text { Submit contractor's request for } \\
\text { payment }\end{array}$ & \\
\hline 5.02 & Earthwork \& grading & \\
\hline 5.06 & Provide elevated work platform & \\
\hline 5.09 & $\begin{array}{l}\text { Acquire \& record material lab test } \\
\text { results }\end{array}$ & \\
\hline 6.02 & Train facility operators & \\
\hline 6.03 & $\begin{array}{l}\text { Use as-built information in operator } \\
\text { training }\end{array}$ & \\
\hline 6.07 & $\begin{array}{l}\text { Request facility maintenance or } \\
\text { modifications }\end{array}$ & \\
\hline 6.08 & $\begin{array}{l}\text { Update as-built drawings in response } \\
\text { to facility modifications }\end{array}$ & $\mathrm{X}$ \\
\hline
\end{tabular}

\subsection{Characterizing Work Functions}

For each subject work function, the survey asks participants to assess the extent to which individual WFCs apply to that work function. This survey offers respondents five optional responses: Strongly Agree, Agree, Neutral, Disagree, or Don't Know. For any given WFC, the assessed degree to which a 
Table 4. Selected Work Functions for WFC Analysis

\begin{tabular}{|c|l|c|c|}
\hline ID & \multicolumn{1}{|c|}{ Work Function } & $\begin{array}{c}\text { Responsible } \\
\text { Organization }\end{array}$ & Leverage \\
\hline 2.11 & $\begin{array}{l}\text { Detect physical } \\
\text { interferences }\end{array}$ & A/E & Schedule \\
\hline 2.14 & Track design progress & A/E & Cost \\
\hline 3.04 & $\begin{array}{l}\text { Link between supplier cost } \\
\text { quotes and cost estimate }\end{array}$ & GC & Schedule \\
\hline 4.13 & Update as-built drawings & GC & Cost \\
\hline 4.14 & $\begin{array}{l}\text { Submit contractor's request } \\
\text { for payment }\end{array}$ & GC & Schedule \\
\hline 5.02 & Earthwork \& grading & GC & Schedule \\
\hline 5.06 & $\begin{array}{l}\text { Provide elevated work } \\
\text { platform }\end{array}$ & GC & Schedule \\
\hline 5.07 & Fabricate roof trusses & GC & Cost \\
\hline 6.02 & Train facility operators & Owner & $\begin{array}{c}\text { Cost \& } \\
\text { Schedule }\end{array}$ \\
\hline 6.08 & $\begin{array}{l}\text { Update as-built drawings in } \\
\text { response to facility } \\
\text { modifications }\end{array}$ & Owner & Cost \\
\hline
\end{tabular}

WF relates to that WFC was established as the WFC Score. In order to perform quantitative analysis, responses were converted to WFC Scores as follows: Strongly Agree $=4$, Agree $=3$, Neutral $=2$, and Disagree $=1$. The WFC applicability index was computed and then translated to a $0-10$ point score:

Mean WFC Applicability Index $=[($ Sum of WFC Scores associated with all project performance-leveraging WFs / Total number of project performance-leveraging WFs)-1] * 10/3

A WFC Applicability Index score of zero indicates "not applicable." A value of 6.67 or greater indicates "highly applicable." Figure 1 illustrates the degree to which individual WFCs relate to the cost and schedule performance-leveraging WFs. The plot is divided into four quadrants. The points located at the upper right quadrant represent WFCs with high applicability for both cost and schedule leveraging WFs. If a data point is located in the lower left quadrant, it indicates that the WFC has little applicability to the leveraging WFs. Figure 2 displays the data set representing the WFCs that may explain leveraging. Each data point represents a Work Function Characteristic. The farther to the right a point is located, the more strongly the WFC is associated with the cost performance-leveraging WFs. Similarly, the higher a point is located, the more strongly the WFC relates to the schedule performance-leveraging WFs.

\subsection{Identification of Common WFCs Trends}

Mean WFC applicability index values of 6.67 or greater are associated high applicability WFCs. Nine WFCs that may explain leveraging were identified in the WFC analysis. These WFCs show a strong association with the cost and/or schedule performance work functions. Table 5 presents the high applicability WFCs. Most of the WFCs that may explain leveraging fall in the following three WFC categories: 1) human resource, 2) information \& data, and 3) management. This indicates that information/data-intensive, human resource involved, and management-related WFCs may greatly influence project cost and schedule success.

Work Function Characteristics that may explain cost performance-leveraging were identified in order to explore project cost success determinants. The analyses suggest that data/informationintensive and management-related Work Function Characteristics may greatly influence the cost performance of a project. Work functions that involve significant amount of data updating and repetitive activities deserve the execution with high technology approaches. In addition, degrees of technology used in executing the work functions that involve many different types of organizations and frequent communication between individuals likely affect the cost performance of a project. The priority for technology implementation is also associated with the work functions for which data accuracy and user's experience are critical to performance.

Work Function Characteristics that may explain schedule performance-leveraging were identified to further explain the links between technology utilization and project schedule success. The analysis results indicate that data/informationintensive and human resource involved Work Function Characteristics may have potential influence on the schedule performance of a project. Technology usage for work functions associate with historical data and data security may help improve project schedule performance. Consideration should be also given to employ higher levels of technology usage for the work functions that 
involve many individuals and personnel communication. In addition, the priority for technology implementation is associated with the work functions for which data accuracy and user's experience are critical to performance.

\section{CONCLUSIONS}

The techniques used for analyzing the associations between technology usage and project success include cost performance sensitivity, schedule performance sensitivity, and analysis of Work Function Characteristics. Cost and schedule performance sensitivity analyses of project performance-leveraging work functions were used as a way to gain greater understanding of the connection between technology usage and project success. WFCs were also investigated as an additional basis for gaining deeper insights into how technology usage may impact the cost and schedule performance of a project. The results indicate that the project performance-leveraging work functions involve factors or characteristics that may affect project cost and schedule success. These analyses also suggest that data/information-intensive, human resource involved, and managementrelated Work Function Characteristics may greatly influence the cost or schedule performance of a project. Work functions that involve data accuracy and frequent communications between different individuals and organizations deserve the high technology approaches in order to achieve higher levels of project cost and schedule success. In addition, the priority for technology implementation is also associated with the work functions for which worker's or operator's experience is critical to performance.

\section{REFERENCES}

[1] O'Connor, J. T., and Yang, L. (2002). "Project Performance vs. Use of Technologies at the Work Function Level." International Symposium for Automation in Construction, September 2002, Washington, D.C.

[2] Won, S. (2002). "A model for work functionbased prioritization of technologies for capital projects." PhD thesis, University of Texas, Austin, Texas.

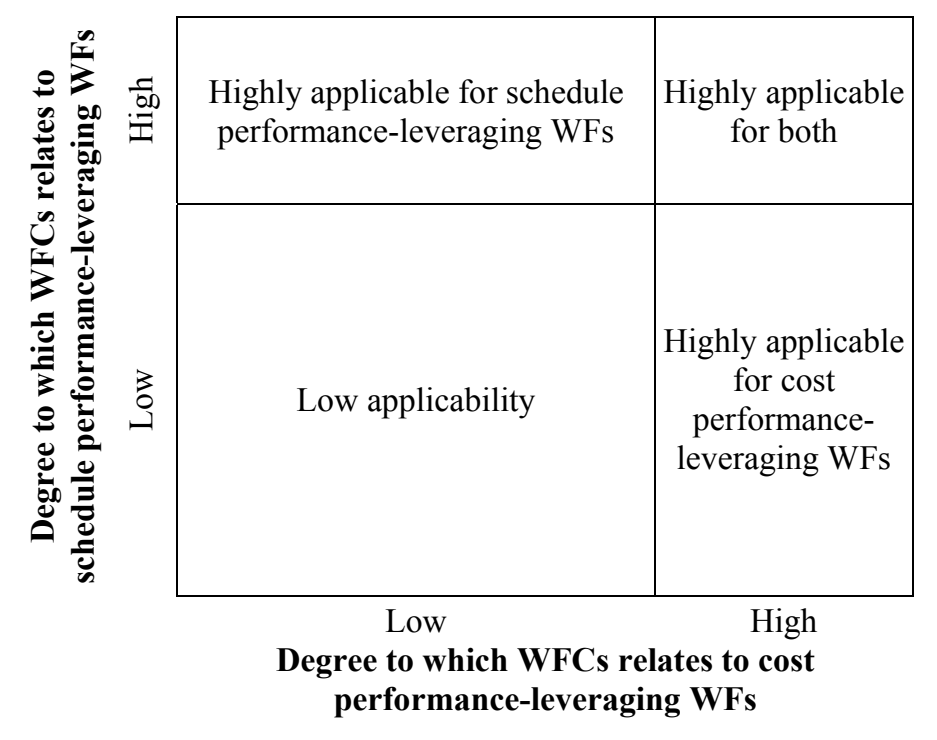

Figure 1. Relationships between WFCs and Project PerformanceLeveraging $W F s$ 


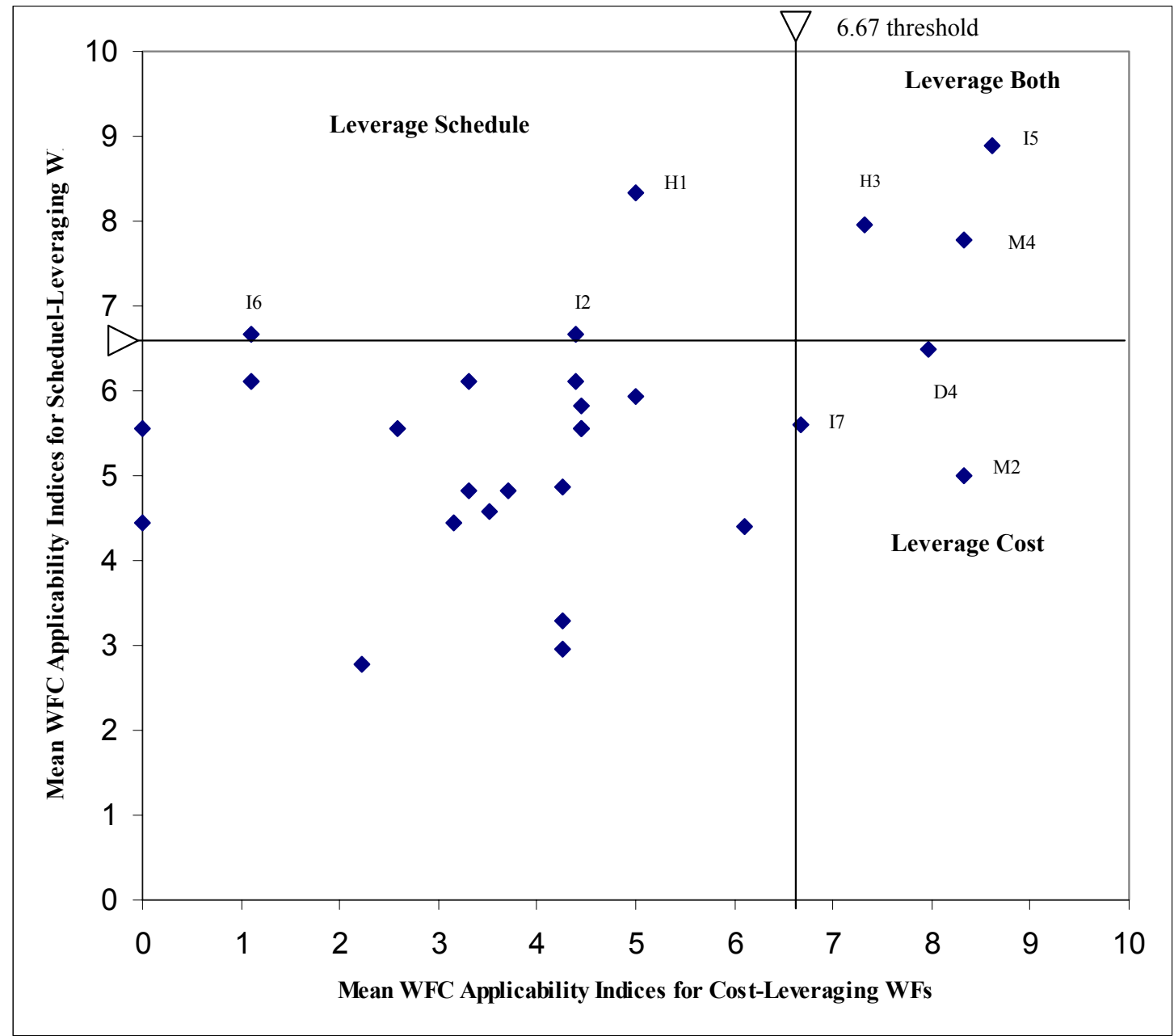

Figure 2. WFC Analysis for Project Performance-Leveraging WFs

Table 5. WFCs That May Explain Leveraging

\begin{tabular}{|l|l|c|c|}
\hline \multicolumn{1}{|c|}{ Category } & \multicolumn{1}{|c|}{ WFCs } & $\begin{array}{c}\text { Cost } \\
\text { Leverage }\end{array}$ & $\begin{array}{c}\text { Schedule } \\
\text { Leverage }\end{array}$ \\
\hline \multirow{5}{*}{ Human Resource } & H1: Many individuals are involved in the WF & & $\mathrm{X}$ \\
\cline { 2 - 4 } & $\begin{array}{l}\text { H3: User's, worker's or operator's experience is critical to } \\
\text { performance }\end{array}$ & $\mathrm{X}$ & $\mathrm{X}$ \\
\hline \multirow{5}{*}{$\begin{array}{l}\text { Information \& Distorical data from previous projects are required for } \\
\text { execution }\end{array}$} & $\begin{array}{l}\text { I5: Data accuracy is crucial to successful WF } \\
\text { performance }\end{array}$ & $\mathrm{X}$ & $\mathrm{X}$ \\
\hline & I6: Security of related data is very important & $\mathrm{X}$ \\
\hline & I7: WF involves significant amount of data updating & $\mathrm{X}$ & \\
\hline \multirow{2}{*}{ Management } & M2: Many different types of organizations are involved & $\mathrm{X}$ & \\
\cline { 2 - 4 } & $\begin{array}{l}\text { M4: Responsible individual must communicate frequently } \\
\text { with others }\end{array}$ & $\mathrm{X}$ & $\mathrm{X}$ \\
\hline Work Procedure & D4: WF involves repetitive activity & $\mathrm{X}$ & \\
\hline
\end{tabular}

